\title{
Annual Changes in Testicular Size and Serum and Fecal Testosterone Concentrations in Male Bharals, Pseudois nayaur
}

\author{
Satoshi KUSUDA ${ }^{1)}$, Hirotada NAGAMI'), Hiroshi KUSUNOKI ${ }^{3)}$, Tomoya NISHIKAKU ${ }^{4)}$, Daisuke NAKAGAWA ${ }^{4}$, \\ Toyoharu TAKIDA ${ }^{4}$, Daisuke KURITA ${ }^{4)}$, Koji UEMICHI ${ }^{4)}$, Masaki FUKAI ${ }^{4}$, Hiroshi KUBOTA ${ }^{4)}$, Kaoru UEDA ${ }^{4)}$, \\ Tomoko OOE ${ }^{4}$, Kazuo OKUDA ${ }^{4)}$, Kayoko $\mathrm{UEDA}^{5)}$ and Osamu $\mathrm{DOI}^{5) *}$ \\ ${ }^{1)}$ United Graduate School of Agricultural Science and ${ }^{2)}$ Graduate School of Agriculture, Gifu University, Yanagido, Gifu 501-1193, \\ ${ }^{3)}$ Faculty of Agriculture, Kobe University, Rokkodai-cho, Nada-ku, Kobe, Hyogo 657-8501, ${ }^{4)}$ Himeji Central Park, Kodani-aza-okura, \\ Toyotomi-cho, Himeji, Hyogo 679-2121 and ${ }^{5}$ Faculty of Applied Biological Sciences, Gifu University, Yanagido, Gifu 501-1193, Japan
}

(Received 17 October 2005/Accepted 1 June 2006)

ABSTRACT. The serum and fecal testosterone (T) concentrations and testicular sizes of two male bharals (Pseudois nayaur) were determined for approximately one year. The profiles of the fecal $\mathrm{T}$ concentrations showed a similar tendency as the profiles of serum $\mathrm{T}$ concentrations, and there was a significant correlation between serum and fecal $\mathrm{T}$ concentrations $(\mathrm{r}=0.72)$. $\mathrm{T}$ concentrations rose drastically in October and decreased gradually until January. The maximum testicular size was observed between November and January. Semen collected between December and January was excellent in quality and comparable to domestic sheep and goats. The active periods of the testes were synchronized with the early breeding season of females.

KEY WORDS: bharal, testis, testosterone.

J. Vet. Med. Sci. 68(10): 1093-1095, 2006

The bharal (blue sheep: Pseudois nayaur) belongs to the subfamily Caprinae, family Bovidae, and inhabits the undulating montane zone from the Himalayan region to Inner Mongolia [9, 11]. P. schaeferi and a portion of the regional populations of $P$. nayaur are in a critical situation because of excessive hunting for meat that occurred before hunting was legally banned in 1989 and poaching thereafter. According to the 2004 IUCN Red List of Threatened Species [1], $P$. nayaur is classified as low risk (near threatened) and $P$. schaeferi as endangered, so the necessity to conserve wild and captive populations has risen.

It is known that the bharal is a seasonal breeding animal. The mating season is in October-January and the birth season is in May-July in natural habitats [9]. Although seasonal changes in the gonadal morphology and histology, behavior, and/or reproductive hormones such as testosterone (T) have been reported for the male red deer (Cervus elaphus), white-tailed deer (Odocoileus virginianus) [5, 6], sika deer (C. nippon) [10], mouflon (Ovis musimon) [6, 7], and others [13], that of the male bharal has yet to be reported. The purpose of the present study was to clarify the annual changes in the serum and fecal $\mathrm{T}$ concentrations and testicular size and then to collect basic information on the breeding season of male bharals.

Two male bharals (No.1; name, Sansi; date of birth, June 1, 1999; body weight, $42.8 \mathrm{~kg} /$ No.2; Tianjin; June 13, 2000; $43.7 \mathrm{~kg}$ ) housed in Himeji Central Park were studied from July 2003 to July 2004. During this study period, the two male bharals were kept in an outdoor paddock approximately $45 \mathrm{~m}^{2}$ in size. The bharals were fed a daily diet of

\footnotetext{
* Correspondence to: Doi, O., Laboratory of Animal Reproduction, Faculty of Applied Biological Sciences, Gifu University, Yanagido, Gifu 501-1193, Japan.
}

approximately $500 \mathrm{~g} / \mathrm{head} /$ day of alfalfa and timothy hay and approximately $500 \mathrm{~g} /$ head/day of pellet ZC (Oriental Yeast). Drinking water was provided ad libitum.

Blood and feces were collected weekly for approximately one year. Blood was collected from the jugular vein without anesthesia. Immediately after blood sampling, the blood was put into evacuated blood collection tubes containing a serum-separating medium. The tubes were left for approximately $30 \mathrm{~min}$ at room temperature, and then the serum was separated from the whole blood by centrifugation at 3,000 $\mathrm{rpm}$ for $10 \mathrm{~min}$. The serum samples were stored at $-20^{\circ} \mathrm{C}$ until assay. Feces were collected immediately after excretion on the same day of blood sampling and stored at $-20^{\circ} \mathrm{C}$ until assay. For the T assay, the steroid in the serum samples was extracted twice with diethyl ether. Fecal samples were extracted using a methanol extraction method as reported previously [2]. Briefly, fecal samples were frozen and lyophilized for approximately $24 \mathrm{hr}$ and then pulverized. A $0.1 \mathrm{~g}$ portion of the dry powder was then extracted with $80 \%$ methanol in $5 \mathrm{ml}$ of water by vortex-mixing for 30 min. After centrifugation at 2,500 rpm for $10 \mathrm{~min}, 100 \mu \mathrm{l}$ of the supernatant (methanol fraction) was removed into a clean tube and evaporated to dryness. This sample was reconstituted at a dilution of 1:5 using 0.01 $\mathrm{M}$ phosphate buffered saline (PBS). Radioimmunoassay was carried out by a previous method [3] using $\left[1,2,6,7-{ }^{3} \mathrm{H}\right]$ radiolabeled $\mathrm{T}$ (10,000 dpm/50 $\mu l$, NET517, Amersham Pharmacia Biotech) and T antiserum (1:100,000, ED-131, Teikoku Hormone Mfg Medical). The antiserum cross-reactivity is as follows: $100 \%$ for $\mathrm{T}, 41.3 \%$ for $5 \alpha$-dihydrotestosterone, $2.07 \%$ for androstenedione, $0.80 \%$ for epitestosterone, $0.07 \%$ for androsterone, $0.04 \%$ for deoxycorticosterone, $0.02 \%$ for dehydroepiandrosterone, $0.02 \%$ for progesterone, and $<0.01 \%$ for etiocholanolone, $17 \alpha$-hydroxyprogester- 
one, cortisol, corticosterone, and cortisone. The fecal T concentrations are expressed as the amount included in $1 \mathrm{~g}$ of dry feces powder.

Testicular size (scrotum size including the testis, epydidymis, and surrounding skin) was measured on the same day as blood and feces sampling. To measure the size without anesthesia, the bharals were restrained by two staff clutching both horns and hind legs, respectively. The sizes of the right and left testes (length, width, and depth) were measured three times using an electronic caliper square by 2 or 3 staff in turn each time. Testicular size data are expressed as the mean of three measured values.

Semen samples were collected 5 times for No. 1 and 2 times for No.2 between December 22, 2003 and January 17, 2004 , respectively. A warmed artificial vagina for rams and goats $(200 \mathrm{~mm}$ in length and $44 \mathrm{~mm}$ in inner diameter, NFA260, Fujihira Industry) was used with a teaser female. Immediately after collection, the volume and $\mathrm{pH}$ of the ejac- ulates and sperm concentration, motility, and viability were evaluated by previous methods [4].

It has been reported that wild male bharals usually reach full growth body size at 5-7 years old $[12,13]$ and that they cannot copulate prior to that age [9]. The ages of the two males used in this study were 4 years and 1 month and 3 years and 1 month, respectively, when sample collection began. However, they had a successful breeding before this study began, so they had already reached sexual maturation. Under a good nutritional environment, such as in captivity, and conditions where more dominant males are absent from the herd, the male probably reaches sexual maturation and can copulate earlier than 5-7 years old. We clarified the annual changes in the testicular sizes and serum and fecal $\mathrm{T}$ concentrations in sexually matured male bharals. The results for the two males are shown in Fig. 1.

The minimum sizes of testis length, width, and depth were observed in August, and the maximum sizes were
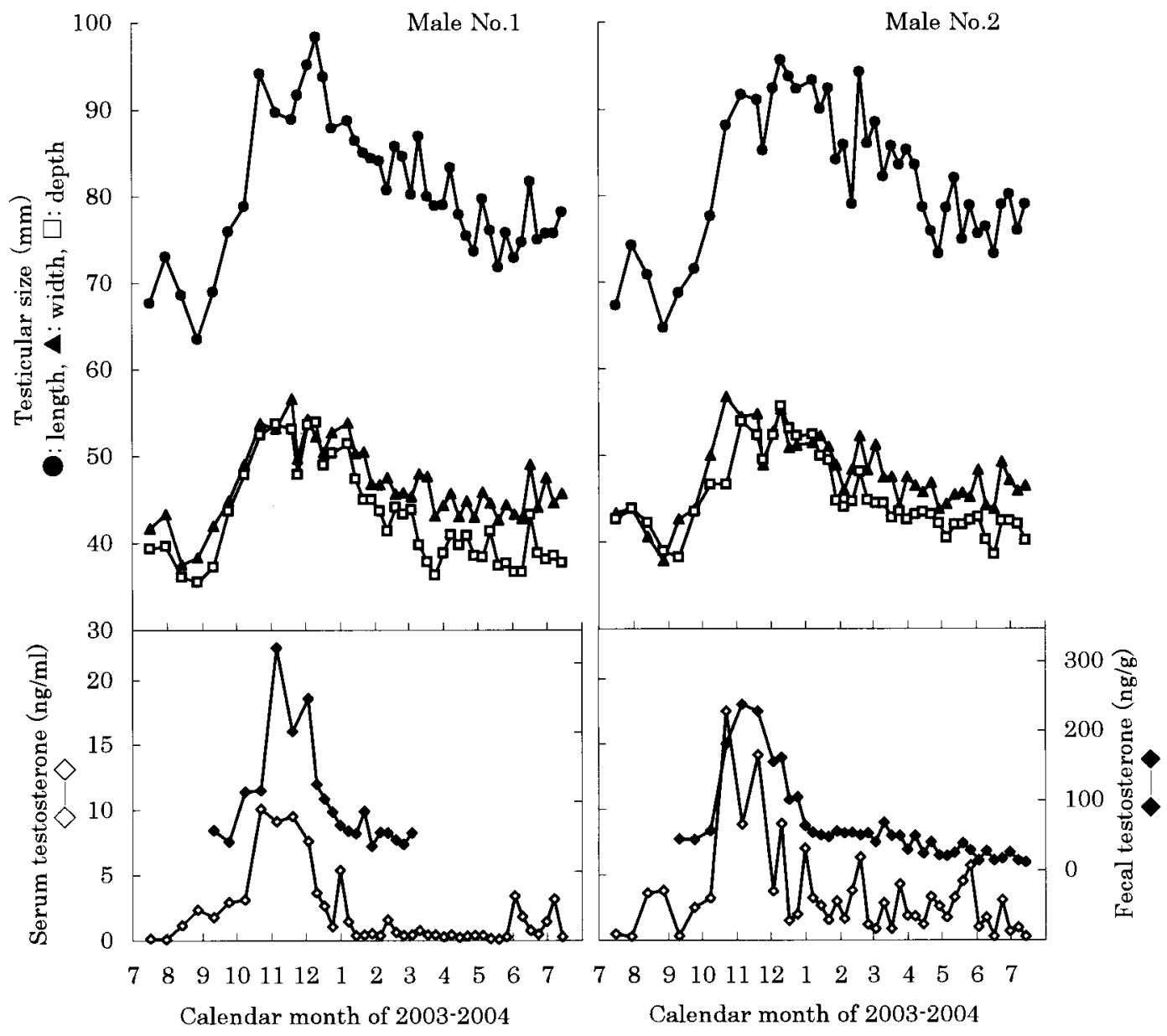

Fig. 1. Annual changes in length, width, and depth of the left testis and serum and fecal testosterone concentrations in two male bharals. 
observed from November to January. Changes in the length were the most remarkable. The minimum value of the length was $63 \mathrm{~mm}$ in No.1 and $64 \mathrm{~mm}$ in No. 2. Thereafter, the length increased rapidly and reached a peak value of 98 $\mathrm{mm}$ in No. 1 and $95 \mathrm{~mm}$ in No. 2 in December. Testis sizes gradually became smaller starting in December in No.1 and starting in January in No. 2. The length and depth of the testis changed in the same manner.

Serum $\mathrm{T}$ concentrations rose drastically in both males in October and then reached a peak value of 10.1 and $17.5 \mathrm{ng} /$ $\mathrm{m} l$, respectively. Thereafter, serum $\mathrm{T}$ concentrations decreased until January. Fecal $\mathrm{T}$ concentrations in both males indicated a peak value of 321.8 and $238.5 \mathrm{ng} / \mathrm{g}$ in November, respectively. The profiles of the fecal T concentrations showed an extremely similar tendency to the profiles of the serum $\mathrm{T}$ concentrations. There was a high positive correlation between $\mathrm{T}$ values in the serum and feces, and the correlation coefficient was $0.72(n=59$ from the 2 males, $\mathrm{p}<0.01 ; \mathrm{y}=0.04 \mathrm{x}+0.43$ ). For $\mathrm{T}$ assay, the feces were used instead of blood so there was no stress on the animals and no exposure to danger for collection staff during sample collection. Our results suggest that measurement of the fecal $\mathrm{T}$ concentrations was very useful as a noninvasive endocrine assessment technique for male bharals.

The peaks of the testicular size and $\mathrm{T}$ concentrations in the male bharals were from late October to December. The breeding season (cyclicity of serum progesterone) of the female bharals kept at the same facility is from November/ December to May/June based on our research results [3]. Therefore, the peaks of spermatogenic and T secretory ability in the males were synchronized with the early breeding season of the females. The males might ensure maximal sperm production when females become sexually receptive.

Although the peaks of the $\mathrm{T}$ concentrations and testicular size were almost the same time, the period of the high $\mathrm{T}$ values was shorter than that of the large testis. It has been reported that a large amount of $\mathrm{T}$ secretion period was shorter than the period of active spermatogenesis in wild sika deer [10] and white-tailed deer, etc. [5]. As a result of semen collection between December and January (Table 1), the semen quality was excellent and comparable to that reported in domestic sheep and goats [8]. These male bharals were housed together with two females in the same paddock from March 18 to July 15, 2004. Sexual behaviors, such as chasing and mounting the females, were observed from March to April and consequently one female became pregnant. These results seem to indicate that the potential fertility of these males was not lost, at least from December to April, in spite of the period of low T levels. The potential fertility of the males might be maintained until the end of the breeding season [3] of females. It has been illustrated that the secretion period of a large amount of fecal $\mathrm{T}$ in the male sika deer ended before the onset of the estrous cycle (cyclicity of fecal progesterone) in the female [14]. T secretion has been considered to play an essential role in the aggressive
Table 1. Characteristics of semen from two male bharals

\begin{tabular}{lcc}
\hline Male & No.1 & No.2 \\
\hline No. of collections & 5 & 2 \\
Average quality & & \\
$\quad$ Semen volume $(\mathrm{m} l)$ & 1.60 & 0.95 \\
Seminal pH & 6.8 & 7.0 \\
Sperm concentration $\left(\times 10^{6} / \mathrm{m} l\right)$ & 7091.7 & 1437.0 \\
Sperm motility & $75+++$ & $85+++$ \\
Sperm viability $(\%)$ & 76.2 & 84.1 \\
\hline
\end{tabular}

behavior concerning territory competition to obtain females at/before the onset of the breeding season of females [14]. In the male bharal, a large amount of $\mathrm{T}$ secretion might be associated with aggressive behaviors.

The present study indicated that fecal $\mathrm{T}$ assay was a useful tool for non-invasively assessing the changes in circulating $\mathrm{T}$ concentrations in male bharals. Furthermore, we provided basic information on the seasonality of testis activity in male bharals.

\section{REFERENCES}

1. IUCN. 2004. 2004 IUCN Red List of Threatened Species. Available from http://www.redlist.org/. Downloaded on 30 September 2005.

2. Kusuda, S., Nagami, H., Nishikaku, T., Nakagawa, D., Takida, T., Kurita, D., Uemichi, K., Fukai, M., Kubota, H., Ueda, K., Ooe, T., Okuda, K., Hama, N., Kusunoki, H. and Doi, O. 2006. Jpn. J. Zoo. Wildl. Med. 11: 49-56 (in Japanese with English summary)

3. Kusuda, S., Nagami, H., Ueda, K., Doi, O., Nishikaku, T., Nakagawa, D., Takida, T., Kurita, D., Uemichi, K., Fukai, M., Kubota, H., Ueda, K., Ooe, T., Okuda, K. and Kusunoki, H. 2006. J. Vet. Med. Sci. 68: 847-851.

4. Kusunoki, H., Nishikaku, T., Nakagawa, D., Takida, T., Kurita, D., Uemichi, K., Ueda, K., Ooe, T., Okuda, K., Kusuda, S. and Doi, O. 2005. Jpn. J. Zoo Wildl. Med. 10: 91-94.

5. Lincoln, G. A. 1985. pp. 165-179. In: Biology of Deer Production (Fennessy, P. F. and Drew, K. R. eds.), The Royal Society of New Zealand, Wellington.

6. Lincoln, G. A. 1989. pp. 329-385. In: The Testis (Burger, H. and Kretser, D. eds.), Raven Press, New York.

7. Lincoln, G. A. 1998. Anim. Reprod. Sci. 53: 87-105.

8. Mann, T. and Lutwak-Mann, C. 1981. Male Reproductive Function and Semen. Springer-Verlag, New York.

9. Nowak, R. M. 1999. pp. 1228-1229. In: Walker's Mammals of the World Vol. II, 6th ed, Johns Hopkins Univ. Press, London.

10. Suzuki, M., Kaji, K. and Nigi, H. 1992. J. Vet. Med. Sci. 54: 551-556.

11. Wang, X. and Hoffmann, R. S. 1987. Mammalian Species 278: $1-6$.

12. Wegge, P. 1979. J. Asian Ecol. 1: 10-20.

13. Wildt, D. E. 1996. pp. 429-450. In: Wild Mammals in Captivity (Kleiman, D. G. ed.), Univ. Chicago Press, Chicago and London.

14. Yamauchi, K., Hamasaki, S., Takeuchi, Y. and Mori, Y. 1997. J. Reprod. Dev. 43: 221-226. 